\title{
Student in information society: indicators of socio-moral development of individual in quality education evaluation
}

\author{
Natalia N.Naydenova ${ }^{1, *}$ and Tatiana D.Shaposhnikova ${ }^{1}$ \\ ${ }^{1}$ ISED RAE, Center of comparative education, 105062, Moscow, Russia
}

\begin{abstract}
Urgent questions for measuring a quality of education and its most important component, a personal development of students in the digital environment is raised in this article. The aims and outcomes of today's school activities are to improve the quality of education, which is measured not only in knowledge and skills or competences, but also in acquiring by student's ethical moral culture and moral values and norms of world civilization and our society. The most important indicator of the quality of education today are characteristics of personal development of pupils, their ethical, moral and ethical culture, ethical principles of behavior motivation. However, diagnosis in the field of pedagogical activity seems to researchers one of the most complex and elusive. Especially it concerns the evaluation criteria of pupils' upbringing. The paper analyzes the techniques that are operated today in a pedagogical science and practice in the field of measurement of a direction of the quality of education.
\end{abstract}

\section{Introduction}

Information civilization is characterized by the fact that there are more and more opportunities for interaction: between people, in education needs, in implementation of their interests in the digital culture, in preservation of traditional cultures and in formation of a global culture which is focused on universal values and norms. According to the famous American futurist Alvin Toffler, today the information in any civilization with different levels of development becomes more valuable than ever. In addition, a new civilization systematically readjusts education, science and media $[1,76]$.

It should be noted that the role of a super-fast and super-long forms for a communication using the Internet sharply increases in the information society. Informatization of the society has penetrated all spheres of life and inherent to all ages. It is hard to imagine a modern man who acquires knowledge at different levels of education without modern gadgets: smartphones, social networks, chat via Skype and WhatsApp, laptops, etc. As the American scientist D. Tapscott considers, computerization becomes a measure of the progress, it enhances the intellectual capacity of a man and a society and changes the learning process that increases an importance of the socialization $[2,145]$.

The character of communication is changed between people who are active members of the global network by entering into the subject-object relationships in the open spaces of Internet. One can find people in a network similar to him irrespective of a place of residence and create society of adherents. A network promotes changes in a person: there are changes not only in technological base and information technological capabilities of a person, but also in his consciousness. There is formation of the new man in the information society who lives in another information environment. This person can uses symbols, generate knowledge using a modern information technology, realizes himself already as a representative of new information culture.

There is a new mentality in which religious, national and civic identity acquires the information type to a greater extent than the kind of value. It is not surprising, since in the framework of the information society is all seen as information. Information technology determines not only the level of development of productive forces of society but also of. They help not only to receive, to keep, to convert and to transfer information, but also to develop individual's abilities to make new information, new semantic orientations and values Scientists call this man "computer person" $[1,33]$.

\section{Human development in the digital environment}

In the new situation information not only determines events taking place in society, but to a certain extent creates this world, it becomes crucial resource development process of an individual and society. Thus, in a sense, the reality becomes a virtual and informativecommunicative reality. This evolution in the social transformations leads to a change of a learning man. According to experts he becomes the competent person, that is responsible for use and effectiveness of knowledge, skills and competences (P. Drucker) [2, 98].

\footnotetext{
Corresponding author: nnnaydenova@yahoo.com
} 
Competence of a person means not only knowledge of an ethical, moral order, but also ability to position himself in society with certain moral installations. In the information society man's responsibility for his actions increases, he is guided by his own system of moral guidelines. And the future as experts consider, will be society of "total freedom" where an external constraining framework will pass into internal bans: "I will act so not because it is indecent and it will cause condemnation of others, but because I do not want to cause inconvenience to another person" (A. Nikonov). In their choice people will be guided by universal human values. Morality as a system of norms and values is transforming and is filled with a new spiritual and humanistic content. People have the right of moral choice, ability to decide what to do in a particular case, without violating the universal ethical guidelines. It is recognized that the role of an ethical education greatly increases in the educating of the younger generation in the modern life.

According to G. Soldatova today's children are a digital children. The higher mental functions change among the digital aborigines (people born in the digital age): memory is formed differently, storing mechanisms changes; duration of concentration of attention decreases;; sensory perception gets dull, there is change in intellectual and cultural history (the transition from the linear model of thinking to the network model) [6].

American educator M. Prensky called such children digital aborigines, that is, students are digital aborigines and teachers are digital immigrants [7].

Thus current students quite radically differ from teachers in various positions. They in a different way enter communications, exchange opinions and material objects, are engaged in creativity, estimate other people and solve problem social and moral situations; play, study, look for information; discuss, analyze, form messages, socialize, in general grow and develop differently than their parents and teachers.

The network involves multi-tasking, so modern students solve several problems at once. That is usual linear subject training becomes a brake for such learning people.

The current teachers need to understand that we are in a new reality, so you should not try to teach them the way we were taught, and find ways to interact with digital aborigines, that is, teachers and parents as a digital immigrants need to choose the model of socialization in the digital diaspora (8).

In general the American teachers believe that digitalization and the introduction of digital technologies in the educational process has a positive effect on the written language learners $[9 ; 10]$.

Overall assessment of cognition, the ability to write an essay, different kinds of literacy, educational subject achievement, critical thinking is included in the assessment of the quality of education. But in practice, evaluation of social and moral development of an individual is not an element of a coherent integral Educational Quality Assessment, and it must be done now. Only the assessment of the cognitive intelligence without the evaluation of social and emotional intelligence $[11,12]$ does not sufficiently reflect with the multiplex evaluation for the quality of education [13].

\section{Moral values}

The current goal of the school is improving the quality of education in its integral sense. A measured quality of education includes not only a subject achievements, knowledge and skills, but competences, including social and ethical, what is the basis of human civilization and our society [14]. The most important indicators of a quality of education are characteristics of personal, social and moral development of students. These characteristics are outlined in a new generation of standards (Federal State Education Standards - FSES) and related to the development of:

$=$ Russian civil identity, patriotism, democracy, humanism;

=system of views on the world in the unity and diversity of nature, peoples, cultures and religions;

$=$ respect for the other view, the history and culture of other nations;

$=$ adaptation skills to the changing world;

= motivation of educational activity;

$=$ independence and responsibility;

$=$ aesthetic needs, values and feelings;

$=$ ethical feelings of friendliness and responsiveness, empathy;

$=$ cooperation skills of adults and peers;

$=$ orientation to a safe, healthy way of life [15].

Diagnostics in the field of pedagogical activity is a difficult task. But scientists admit that some aspects of student social-moral development can be exposed not only qualitative, but also quantitative assessment. Various techniques for estimating the socio-moral development of individual components include: ideals, values, attitudes orientations, attitudes. Such interdisciplinary studies base on different methodological approaches: philosophical, sociological, psychological, structure-functional, systemic-structural. In terms of philosophical approach the value of the people's associations is scoring by measuring of rights and interests of an individual. A personal installation, a value orientation or a behavior is recognized as rationale for choice of methods in a study (for example, the system of values) according to a sociological approach. Psychologists believe that fixing of values changes is most effective on the basis of observation.

\section{Pedagogical measurements of socio- moral development}

Scientists, teachers (F.N. Kozyrev, N.K. Golubev, B.P. Bitinis, S.V. Yakovlev et al.) offer to study levels of social moral development of students in pedagogical diagnostics [16].Scientists refer supervision, ethical conversations, testing, experiment, the analysis of school documentation, poll to traditional methods of diagnostics of upbringing. At the same time traditional methods of pedagogical diagnostics is supplemented with new contents today. 
Supervision allows solving successfully research problems to teachers in teaching and educational process. Experts suggest strengthening emphasis on fixing of incidents (the extraordinary, surprised teachersresearchers events) which help to disclose in a new way moral qualities of a pupil or all children's collective. A convenient way to fix is an audio or video recording of lessons: analysis of incidents during lessons can help to understand some of the communication problems and interaction between actors. As a rule, such incidents are perceived differently if a teacher joins incident. Continuous supervision and the analysis of incidents will help teachers to make included supervision less subjective, gives the chance to present more exact idea of moral development of a school student in situations of comfort / not comfort, conflictness / absence of conflict. It is possible to provide a more accurate representation about moral development of a student in a comfortable or non-comfortable situation and a conflicting or nonconflicting situation.

A conversation is already familiar to teachers in school survey. This method enables to a teacher to carry out a research (diagnostic) action and an education function. If diagnosis is carried out with an outsider it is best to use an interview. A combination of research and observation is successful when wearing an open character - it gives the opportunity to receive information in a concentrated form. Subject interviews can be designed either partially or completely. Group interviews are still rarely used in education research. With its help it is possible to examine individual orientation of students to observe characteristics of their interpersonal relationships.

In a survey it is possible to diagnose anonymously. In a questionnaire students can openly express their views and beliefs. Therefore the survey results are considered reliable and adequate. However, it should be noted that these benefits would be realized, it is essential to create the appropriate conditions for carrying out the study: must be invited the specialist and respondents should be guaranteed confidentiality. The limitation of this type of study is that it is used only to determine the moral status of the group and not the individual. The questionnaire is most often used the five-point Likert scale. Respondents were asked to choose from several options of a ready response. The degree of agreement with a particular option may also be ranked.

Testing is actively used practice of teachers and scientists, because it is the most technologically advanced kind of diagnostic. A test differs from a questionnaire survey that a test for a student is an exam. The peculiarity of it is that objectives of testing and a subject often remain hidden for students. A researcher which conducts testing sees it as a process that they are not only controlled, but also require strict compliance with procedures, processing and interpretation of results. Most often testing is in a encrypted form, and its diagnostic tool includes a key for decrypting data and quantitative criteria for a scoring.

Study of school documentation and training school work is a natural component in the pedagogical process. Compositions of pupils, project works on moral subjects, and products of out-of-class and after-hour work of school students are especially interesting. It is more expedient for them to be subjected to processing by the content analysis.

Pedagogic experiment is also an important diagnostic tool. There often is a new education system, a method or a model as a diagnostics object. The aim of an experiment can be actual checking or analysis of a present system (ascertaining experiment), then its objects are actors of pedagogical interaction. During the experiment the monitoring of pedagogical phenomena carried out in a situation which is created artificially [17].

The use of the experimental method to diagnose social and moral development of a student is possible within the framework of an everyday school life. The experiment can be built on the principle of situational moral choice in a new situation. To create such a situation role-playing games are good. For example, the days of self-government of the school student practiced in many regions of the country. It allows a teacher to enrich their understanding of a student moral world observing their behavior in simulated and unusual situation. [18].

\section{Criteria for assessing of upbringing}

According to an authoritative statement of experts (N.F. Kozyrev) an assessment combines the features of an ideographic (aimed at the definition of the object unique (in this case, the identity of the student) and a nomothetic (oriented to establish quantitative relationships and patterns between objects) discipline. Estimated (nomothetic) diagnostic procedure requires to develop criteria which a researcher applies to make the diagnostic findings (these criteria can be measured quantitatively to associate and to compare). Development of criteria and indicators of aesthetic and moral culture personality is complex and independent scientific and methodological problem. Here domestic pedagogy makes only first steps. The theory of education differs hard and soft, quantitative (statistical) and qualitative evaluation criteria. The first criterion is rarely used in education research. They are used to determine the state of morals in the age group of large-scale studies in sociology. Among these criteria, for example, can be statistics showing the number of violations of children with behavioral problems, drug users, etc. or data on the number of students who are the winners of contests and competitions, and others.

For example a widespread in the Soviet school score for the "behavior" (four-point scale) is that which the main shortcomings are voluntarism and subjective assessments. In recent years schools used diagnostic card, comprising a plurality of indicators. The estimation of the teaching methods to students' self-esteem was borrowed from the medical practice Concilia (diagnostic technique N.P. Kapustin and M.I. Shilova involves selfesteem education of pupils by 40 indicators, including ten characteristics: 1) the duty and responsibility, 2) thrift; 3) discipline, 4) a responsible attitude to learning; 
5) the attitude toward labour; 6) collectivism, camaraderie; 7) kindness and sympathy; 8) honesty and fairness; 9) the simplicity and modesty; 10) the cultural level.

Today the list of individual behavior characteristics differs in different methods. General framework basis for its standards in elementary school F.N. Kozyrev proposes to use FSES requirements to the results of personal development by primary education program he says about the willingness and ability of students to self-development, formation of their motivation to learn and the knowledge, values and meanings facilities, social competencies; formation of civil identity[19].

Modern diagnostics methods for the values system of students, as a rule, are built on classical test of the value orientations M. Rokeach, in which student is offered an expanded in order of importance a set of 18 "terminal" and 18 "instrumental" values. It is supposed to represent the orientation of the tested student - that is something that we should strive (value-targets), and what we must have in order to achieve the objectives (value-funds). Each value corresponds to a score: the most significant 1 , the least significant - 18. On the basis of distributions received from the student we should be received his value preferences and aspirations. The test results can be processed statistically by calculating the average scores of each value (the sum of all scores obtained this value in the test group divided by the number of members of the group), indicators of variations, regression, factor and other types of analysis. Remark of authors: according to the modern theory of testing importance is tested from minimum to maximum, that is it is the higher than a point, the value is more significant if she has positive coloring and vice versa. The interdisciplinary approach is now increasingly used in the diagnosis of the quality of pedagogical education, where an important place occupied by the problem of diagnosing the social and moral development of an individual, due to development of functional mechanisms of mentality (memory, perception, speech, etc). To be fair, these diagnostic indicators important to protect as much as possible from influence of cultural and development due to the typological properties of a person; they include and value orientation and motivation. The developers of these methods are based on the findings of studies on the structural theory of personality development (Piaget, L. Kohlberg, C. Gilligan, J. Fowler, B. Selman, D. Lasker et al.). According to modern Russian scholars - adherents of the theory of Piaget's general diagnosis of personality development must be linked with changes in mental abilities of the child's age. The moral formation of the person depends on the development of mental (cognitive). To become more moral - it means, first of all, to have more advanced thinking abilities, to be able to think logically, to be able to embrace the reality of the existence of another "I"[20].

\section{Conclusion}

Analysis of the issues on pedagogical diagnostics, according to the authors may help teachers in their research and educational activities. You should only remember that the approach to deal with these difficult issues should be cautious objective assessment of student motivation and values built according to the age characteristics of children - it may not always be adequate - the likelihood of such inadequacy is increased with decreasing age of tested students. The choice of methods and teaching techniques of diagnostics should be objective and impartial, with the main criteria and indicators are elected by the student or the level of politeness, or the level of development of students' basic capabilities, or the levels of their intellectual, moral and physical development. The disadvantages of the above diagnostic methods, as well as semi-quantitative approaches should be called selectivity personality traits, which are subject to diagnosis.

In general, in today's information society, the education quality assessment in any education institution should include not only the education diagnosis of cognitive development, but also social and moral. This became especially important now in the era of digitalization: cognition grows and socialization falls. Therefore at a separate assessment of cognitive and social and moral development it is impossible to receive an objective assessment of quality of education both for an individual, and for different stratified groups and institutes of education at different steps of training: from preschool to tertiary.

\section{References}

1. E.Toffler, Tret'ya volna (Ast, Moscow, 1999) [In Rus] 2. D.Tapskott, Elektronno-tsifrovoe obshchestvo. Plyusy i minusy setevogo intellekta (INT Press; Moscow, 1999) [In Rus]

3. L.N. Skvortsov, Informatsionnaya kul'tura i tsel'noe znanie (MBA, Moscow, 2011) [In Rus]

4. P. Draker Postkapitalisticheskoe obshchestvo (Academia, Moscow, 1999) [In Rus

5. A.P Nikonov, Svoboda ot ravenstva $i$ bratstva. Moral'nyi kodeks stroitelya kapitalizma (NTs ENAS, Piter, 2010) [In Rus]

6. G.Soldatova, Deti v informatsionnom obshchestve, 14 (2013) [In Rus]

7. M.Prensky, NCB University Press, 9, 6 (2001)

8. N.Naydenova, Pushkin LSU, 13, 258 (2015)

9. B Klimova, Procedia Technology,1, 85 (2012)

10.G.Fletcher, D.Schaffhauser, and D.Levin, Out of Print: Reimagining the K-12 Textbook in a Digital Age (DCSETDA, Washington, 2012)

11. W.L. Payne, Dissertation Abstracts International, 47, 203A (1983/1986) (University microfilms No. AAC 8605928).

12. N. Naydenova, Competencies and Social-emotional Development, 11, 183 (2014)

13. N.N. Naidenova, Otechestvennaya i zarubezhnaya pedagogika, 1, 224, (2012) [In Rus]

14. T.D. Shaposhnikova, K.V. Savchenko, Osnovy dukhovno-nravstvennoi kul'tury narodov Rossii, (Drofa, Moskva, 2012) [In Rus] 
15. Federal'nyi gosudarstvennyi obrazovatel'nyi standart nachal'nogo obshchego obrazovaniya: tekst s izm. $i$ dop. na 2011 g., (Prosveshhenie, Moscow, 2011) [In Rus]

16. S. V. Yakovlev, Obrazovanie kak integrativnyi faktor tsivilizatsionnogo razvitiya (Taglimat, Kazan', 2015) [In Rus]

17.V.V. Kuchurin, F.N. Kozyrev, and N.V. Firsova; Dukhovno-nravstvennoe $i$ religioznoe obrazovanie $v$ kontekste novykh obrazovatel'nykh standarto (LOIRO, $\mathrm{SPb}, 2011)$ [In Rus]

18. ibidem

19. F.N. Kozyrev, Vestnik RKhGA, 12, 3, 260 (2011) [In Rus]

20.S. V. Yakovlev, Obrazovanie kak integrativnyi faktor tsivilizatsionnogo razvitiya (Taglimat, Kazan', 2015) [In Rus] 